\title{
Postmarketing surveillance of enalapril. II: Investigation of the potential role of enalapril in deaths with renal failure
}

\author{
Christopher J Speirs, Colin T Dollery, William H W Inman, Nigel S B Rawson, Lynda V Wilton
}

\begin{abstract}
The possibility that enalapril might damage renal function was investigated in 1098 deaths recorded in a prescription-event monitoring study. Case notes for 913 patients were examined. In seventy five there was a rise in the urea or creatinine concentration of $\mathbf{5 0 \%}$ or more above pretreatment values. Enalapril appeared to have contributed to a decline in renal function and subsequent death in 10 of these patients. Several characteristics were identified among these patients, including old age, the use of high dose or potassium sparing diuretics, and pre-existing renal disease. Adding a non-steroidal anti-inflammatory drug was also associated with a deterioration in patients with previously stable renal function. No death was encountered of a patient with uncomplicated hypertension.

Enalapril infrequently contributed to a substantial decline in renal function in certain vulnerable patients, especially those receiving other drugs known to be capable of adversely affecting renal function. Awareness of the characteristics of these patients and of their concomitant treatment may serve to reduce the risk.
\end{abstract}

\section{Introduction}

After the introduction of enalapril in April 1985 the manufacturer modified the prescribing information. This was as a result of concern by the Committee on Safety of Medicines about reports of impaired renal function and other adverse reactions, particularly hypotension. ${ }^{1}$ These problems have also been described with another angiotensin converting enzyme inhibitor, captopril..$^{24}$ Prescription-event monitoring was undertaken by the Drug Safety Research Unit on patients who were identified as having been prescribed enalapril in England between April and December 1985. Many had started treatment in hospital earlier in that year. A total of 15169 prescription-event monitoring reports (green forms) were received, including 1098 recording patients as having died. The methods of obtaining these data have been described. ${ }^{\text {s }}$

Department of Clinical Pharmacology, Royal Postgraduate Medical School, London W12 0NN Christopher J Speirs, MRCP, lecturer in clinical toxicology Sir Colin T Dollery, FRCP, professor of medicine

Drug Safety Research Unit, Botley, Southampton William H W Inman, FRCP, director and professor of pharmacoepidemiology Nigel S B Rawson, PHD, principal research officer Lynda V Wilton, PHD, senior research officer

Correspondence and requests for reprints to: Professor W H W Inman, Drug Safety Research Unit, North Croft House,

Winchester Road, Botley, Southampton $\mathrm{SO} 32 \mathrm{BX}$. of creatinine, urea, and electrolytes. Where this information was incomplete further details were sought from 55 hospitals, of which 42 responded.

Thirty of these 142 records were unassessable because there were no measurements of creatinine or urea. The remaining 112 patients with a urea or creatinine concentration documented within one year of the start of enalapril and a further value obtained either when they were prescribed enalapril or within seven days of stopping it were judged to be assessable. In 75 of these 112 cases enalapril had been associated with a rise in the creatinine or urea concentration of $50 \%$ or more. In the remaining 37 there was no evidence of a deterioration in renal function.

\section{Results}

The 75 patients were subdivided into three groups according to the highest creatinine or urea concentration recorded during the year before enalapril treatment began. Twelve patients (group 1) had normal concentrations before enalapril was prescribed (defined in this study as creatinine $<150 \mu \mathrm{mol} / \mathrm{l}$, urea $<10 \mathrm{mmol} / \mathrm{l}$ ); 33 patients (group 2) had a moderate increase in the creatinine or urea concentration before enalapril (creatinine 150-249 $\mu \mathrm{mol} / \mathrm{l}$, urea $10-19 \mathrm{mmol} / \mathrm{l}$ ); and 30 patients (group 3 ) had greatly raised creatinine or urea concentrations before enalapril (creatinine $\geqslant 250 \mu \mathrm{mol} / 1$, urea $\geqslant 20 \mathrm{mmol} / \mathrm{l}$ ).

Enalapril was thought to have contributed to a deterioration in renal function sufficient to be a factor in the subsequent deaths of 10 patients. Three had normal or near normal urea or creatinine values initially (cases 2, 3, and 4) and six had a moderate increase in urea or creatinine (cases $1,5,7,8,9$, and $10)$. In the 30 patients with greatly impaired renal function we could not distinguish a contribution by enalapril except in one borderline case (case 6). The table gives the clinical details of the 10 cases. Several characteristics were identified.

Age - The mean age of the 10 patients was 71 (range 54-85), whereas the mean age of all patients in the main prescription-event monitoring study was 61 (12-99).

Indications for enalapril-Seven patients had heart failure as the indication for enalapril, including two patients with hypertension. In the other three the indication for the drug was hypertension without heart failure.

Diuretics-Nine of the 10 patients were receiving diuretics. Five were taking a loop diuretic and a potassium sparing diuretic simultaneously. Three were taking a loop diuretic alone and one a thiazide and potassium sparing diuretic in a combination tablet. Frusemide was used by seven patients at a mean dose of $126 \mathrm{mg}$ (range $40-200 \mathrm{mg}$ ).

Hyperkalaemia-All 10 patients had a rise in the serum potassium concentration (mean $6.6 \mathrm{mmol} / \mathrm{l}$, range $5 \cdot 6-9 \cdot 4 \mathrm{mmol} / \mathrm{l}$ ) concurrent with their rise in creatinine or urea values. In two patients (cases 2 and 7) potassium concentrations were particularly high (8.9 and $9.4 \mathrm{mmol} / \mathrm{l}$ ).

Fluid loss-The onset of terminal renal failure was preceded by severe diarrhoea in three patients.

Non-steroidal anti-inflammatory drugs-Three of the four patients with late onset deterioration in renal function had been prescribed a non-steroidal 


\begin{tabular}{|c|c|c|c|c|c|c|c|c|c|c|c|}
\hline \multirow[b]{2}{*}{$\begin{array}{l}\text { Case } \\
\text { No }\end{array}$} & \multirow{2}{*}{$\begin{array}{l}\text { Sex } \\
\text { and } \\
\text { age } \\
\text { (years) }\end{array}$} & \multirow[b]{2}{*}{ Indications for enalapril } & \multirow[b]{2}{*}{$\begin{array}{l}\text { Past history of } \\
\text { cardiovascular disease }\end{array}$} & \multirow{2}{*}{$\begin{array}{l}\text { Maximum } \\
\text { daily } \\
\text { dose of } \\
\text { enalapril } \\
\text { (mg) }\end{array}$} & \multirow{2}{*}{$\begin{array}{l}\text { Duration } \\
\text { of } \\
\text { enalapril } \\
\text { (months) }\end{array}$} & \multirow[b]{2}{*}{$\begin{array}{l}\text { Daily dose of other drugs } \\
\qquad(\mathrm{mg})\end{array}$} & \multicolumn{2}{|c|}{$\begin{array}{l}\text { Creatinine } \\
(\mu \mathrm{mol} / 1)\end{array}$} & \multicolumn{2}{|c|}{$\begin{array}{c}\text { Urea } \\
(\mathrm{mmol} / \mathrm{l})\end{array}$} & \multirow[b]{2}{*}{$\begin{array}{l}\text { Other factors implicated } \\
\text { in decline of renal function }\end{array}$} \\
\hline & & & & & & & $\begin{array}{l}\text { Before } \\
\text { enalapril }\end{array}$ & $\begin{array}{l}\text { After } \\
\text { enalapril }\end{array}$ & $\begin{array}{l}\text { Before } \\
\text { enalapril }\end{array}$ & $\begin{array}{l}\text { After } \\
\text { enalapril }\end{array}$ & \\
\hline 1 & F 71 & Cardiac failure & Cerebrovascular accident & $20^{\star}$ & 2 & Frusemide 160 , spironolactone 75 & 77 & 790 & $13 \cdot 0$ & $60 \cdot 0$ & \\
\hline 2 & F 70 & Cardiac failure & - & $10^{\star}$ & 2 & $\begin{array}{l}\text { Frusemide } 160 \text {, potassium } \\
\text { chloride } 1200\end{array}$ & - & 554 & $8 \cdot 8$ & $36 \cdot 0$ & Diarrhoea \\
\hline 3 & M 79 & Cardiac failure, hypertension & $\begin{array}{l}\text { Myocardial infarction, angina, } \\
\text { cerebrovascular accident, } \\
\text { intermittent claudication }\end{array}$ & $10^{\star}$ & 2 & $\begin{array}{l}\text { Frusemide } 120 \text {, potassium } \\
\text { chloride } 1200 \text {, amiloride } 10\end{array}$ & - & 678 & $9 \cdot 7$ & $56 \cdot 0$ & $\begin{array}{l}\text { Bilateral renal artery } \\
\text { stenosis }\end{array}$ \\
\hline 4 & F 85 & Cardiac failure & Angina & $20+$ & 1 & Bumetanide 3 , spironolactone 100 & 107 & 534 & $7 \cdot 3$ & $34 \cdot 0$ & \\
\hline 5 & M 67 & Hypertension & $\begin{array}{l}\text { Transient ischaemic attack, } \\
\text { intermittent claudication }\end{array}$ & $20 \ddagger$ & 9 & $\begin{array}{l}\text { Frusemide } 80 \text { (added after seven } \\
\text { months) }\end{array}$ & - & 1300 & $11 \cdot 0$ & $63 \cdot 0$ & \\
\hline 6 & M 54 & Hypertension & Cerebrovascular accident & $10^{\star}$ & 1 & $\begin{array}{r}\text { Verapamil } 320 \text {, spironolactone } \\
100, \text { hydroflumethiazide } 100\end{array}$ & 253 & 820 & $14 \cdot 0$ & $59 \cdot 0$ & $\begin{array}{l}\text { Previous nephrectomy for } \\
\text { renal haematoma }\end{array}$ \\
\hline 7 & F 81 & Cardiac failure & Myocardial infarction & $10^{\star}$ & 7 & $\begin{array}{l}\text { Frusemide } 120, \text { metolazone } 5, \\
\text { spironolactone } 100 \\
\text { indomethacin } 150\end{array}$ & - & - & $16 \cdot 0$ & $59 \cdot 0$ & Diarrhoea \\
\hline 8 & M 65 & Cardiac failure & Myocardial infarction, angina & $5 \ddagger$ & 8 & $\begin{array}{l}\text { Naproxen } 1000 \text {, frusemide } 200, \\
\text { potassium chloride } 2400\end{array}$ & 180 & 745 & $10 \cdot 0$ & $51 \cdot 0$ & Diarrhoea \\
\hline 9 & F 74 & Hypertension & - & $20 \ddagger$ & 8 & Naproxen 500 & 232 & 821 & $18 \cdot 0$ & $36 \cdot 0$ & $\begin{array}{l}\text { Nephrosclerosis, bilateral } \\
\text { small kidneys }\end{array}$ \\
\hline 10 & M 63 & Cardiac failure, hypertension & Cerebrovascular accident & $10^{\star}$ & 2 & Frusemide 40, amiloride 5 & - & 705 & $15 \cdot 0$ & $40 \cdot 0$ & Bilateral small kidneys \\
\hline
\end{tabular}

*Enalapril started in hospital.

anti-inflammatory agent after enalapril was started, and in two of these the dose of diuretic was also increased (cases 7 and 8).

Withdrawal of enalapril-Enalapril was withdrawn in all 10 patients, but in only one (case 8 ) did the creatinine concentration fall (from 745 to $460 \mu \mathrm{mol} / \mathrm{l}$ ).

Pre-existing renal and vascular disorders-Four patients had evidence of pre-existing renal disease, and in three this had been recognised before enalapril was given. One patient (case 6) had had a previous nephrectomy for a haematoma, the notes of another (case 9) contained a biopsy report noting "nephrosclerosis secondary to hypertension," and two (cases 9 and 10) had bilateral small kidneys shown by ultrasonography. Bilateral renal artery stenosis was found at necropsy in case 3. Interestingly, nine of the 10 patients had suffered 13 distinct manifestations of atheromatous vascular disease in addition to heart failure or hypertension.

\section{Discussion}

Enalapril has been used widely to treat both heart failure and hypertension, with increasing emphasis on heart failure as a result of the publication of evidence for its beneficial effect on mortality in severe congestive heart disease. ${ }^{6} \mathrm{~A}$ postmarketing study of the drug conducted by the manufacturer in patients with hypertension did not discover any cause for concern, and there were no instances of serious renal impairment. ${ }^{7}$ The Committee on Safety of Medicines, however, received a substantial number of reports of hypotension and renal impairment after the drug was marketed. This led to the recommendation that in the treatment of heart failure enalapril should be initiated only in hospital.'

Prescription-event monitoring was started at the same time as the manufacturer's postmarketing study but included a completely different population. In the manufacturer's study there were only 10 deaths in a six week period in 11710 patients, whereas there were 1098 deaths in 15169 patients included in the prescription-event monitoring study, 779 of them occurring within one year after the first prescription. Prescription-event monitoring represents the real world of medical practice and contrasts with the results in selected patients included in the manufacturer's study.

The original green forms had recorded 39 deaths from renal failure and we were particularly concerned that there might be a subgroup of patients with uncomplicated hypertension in whom renal function had deteriorated as a result of treatment. We therefore decided to follow up all deaths, especially those in which no diagnosis was recorded on the green form because the notes had been returned to the family practitioner committee. We were successful in obtaining general practitioner notes in $83 \%$ of all deaths $(913 / 1098)$ in addition to $76 \%$ of those hospital records $(42 / 55)$ that were requested. This illustrates the strength of prescription-event monitoring both as an alerting system and as a database for more detailed investigations.

Ten cases were found in which enalapril appeared to have contributed to a pronounced deterioration in renal function and death. Most of these patients had a history of heart failure and atheromatous disease. From the information available it was not possible accurately to categorise each patient using New York Heart Association criteria. In five patients (cases 3, 6, 8,9 , and 10 ) breathlessness was not enough to restrict them to the home. The other five, however, were breathless either at rest or on slight exertion (that is, grade III or IV). The first year mortality of patients with New York Heart Association grade III or IV heart failure is $48 \%$ and that of patients with chronic stable heart failure $20 \%$ a year. ${ }^{8}$

Inappropriate medical intervention or intercurrent disease contributed to the adverse outcome in several cases. The most prominent was the use of high doses of loop diuretics in combination with the angiotensin converting enzyme inhibitor. The use of progressively higher doses of frusemide in patients with severe heart or renal failure may be hazardous in those who are unable to form normal amounts of angiotensin II. In three patients who had prolonged episodes of diarrhoea angiotensin dependence due to fluid loss may have been a contributory factor in the onset of renal failure. Seven of the 10 patients were also receiving moderate or high doses of potassium conserving diuretics or potassium supplements, or both, and in two of them hyperkalaemia appeared to be the immediate cause of death. There are two reasons why caution should be exercised in the use of drugs such as spironolactone and amiloride in patients receiving angiotensin converting enzyme inhibitors. Firstly, angiotensin converting enzyme inhibition itself may lead to a rise in the serum potassium concentration. ${ }^{9}$ Secondly, renal impairment causes retention of these non-metabolised drugs and increases their effect. ${ }^{10-12}$ If their added diuretic effect causes increased salt and water depletion (as appeared to happen in case 1) this may lead to fatal hyperkalaemia.

Four patients taking enalapril and diuretics 
remained more or less stable for a time but later deteriorated seriously. In three either the dose of diuretics had been increased or a second diuretic had been added. A second important factor in three patients was the addition of a non-steroidal anti-inflammatory drug. Inhibition of the formation of renal prostaglandin by non-steroidal antiinflammatory drugs may cause rapid deterioration of renal function. ${ }^{13-15}$

Among the 142 patients with raised concentrations of creatinine or urea, $28(20 \%)$ had previously received captopril. Of the 771 patients without evidence of renal impairment, $84(11 \%)$ had received captopril. It was not possible to judge whether captopril had already caused some degree of renal impairment in these patients before they began enalapril.

This exhaustive investigation failed to find any patient with mild or moderate uncomplicated hypertension who died of renal failure as a result of taking enalapril. On the other hand, we encountered several important factors which might have been avoided. No unexpected effects of enalapril were found.

We thank the family practitioner committees and the hospitals for case notes, the Office of Population Censuses and Surveys for the death entries, and the general practitioners and consultants who made this study possible. We also thank colleagues who processed the case notes and Mrs Georgina
Spragg for preparing the manuscript. The work was funded in part by a grant from Merck Sharp and Dohme.

1 Committee on Safety of Medicines. Current problems. No 17. London: HMSO, 1986

2 Hollenberg NK. Renal response to angiotensin-converting enzyme inhibition. Am F Cardiol 1983;49:1425-9.

3 Blythe WB. Captopril and renal autoregulation. $N$ Engl F Med 1983;308: 390-1.

4 Schreiber MJ Jr, Fang LST. Renal failure associated with captopril. fAMA 1983;250:31.

5 Inman WHW, Rawson NSB, Wilton LV, Pearce GL, Speirs CJ. Post-marketing surveillance of enalapril. I: Results of prescription-event monitoring. Br Med F 1988;297:826-9.

6 Consensus Trial Study Group. Effects of enalapril on mortality in severe congestive heart failure. N Engl f Med 1987;316:1429-35.

7 Cooper WD, Sheldon D, Brown D, Kimber GR, Isitt VL, Currie WJC. Postmarketing surveillance of enalapril: experience in 11,710 hypertensive patients in general practice. $\mathcal{I} R$ Coll Gen Pract 1987;37:346-9.

8 Wilson JR, Schwartz JS, Sutton MS-J, et al. Prognosis in severe heart failure: relation to hemodynamic measurements and ventricular ectopic activity. f Am Coll Cardiol 1983;2:403-10.

9 Veterans Administration Cooperative Study Group on Antihypertensive Agents. Low dose captopril for the treatment of mild to moderate hypertension. Arch Intern Med 1984;144:1947-53.

$10 \mathrm{Knauf} \mathrm{H}$, Reuter $\mathrm{K}$, Mutschler $\mathrm{E}$. Limitation on the use of amiloride in early renal failure. Eur f Clin Pharmacol 1985;28:61-6.

$11 \mathrm{Knauf} \mathrm{H}$, Mohrke W, Mutschler E. Delayed elimination of triamterene and its active metabolite in renal failure. Eur f Clin Pharmacol 1983;24:453-6.

12 Neale TJ, Lynn KL, Bailey RR. Spironolactone-associated aggravation of renal functional impairment. $N Z$ Med $\mathcal{F}$ 1976;83:147-9.

13 Clive DM, Stoff DS. Renal syndromes associated with non-steroidal anti-inflammatory drugs. $N$ Engl $F$ Med 1983;308:373-6.

14 Cinotti GA, Manzi M, Mene P, et al. Prostaglandin dependence of renal function in chronic glomerular disease. Clin Res 1982;30:445A

15 Favre L, Glasson P, Vallotton MB. Reversible acute renal failure from combined triamterene and indomethacin. A study in healthy subjects. Ann Intern Med 1982;96:317.

(Accepted 10 fune 1988)

\title{
Fertility and legal abortion in England and Wales: performance indicators for family planning services
}

\author{
Michael Clarke
}

\begin{abstract}
The relation between fertility rates and legal abortion rates was investigated in a sample of health authorities in England and Wales to see how these varied. Total period fertility rates and total period legal abortion rates were derived from the average number of live births or legal abortions that would be experienced per woman if women experienced the age specific rates of the year in question throughout their childbearing years. The sample of 30 health authorities was selected by taking the districts with the highest and lowest fertility rates in each English region and in Wales in 1986. Total period fertility rates varied from 1.37 in Riverside to 2.42 in Tower Hamlets, while abortion rates varied from 0.25 in East Yorkshire to $\mathbf{0 . 9 9}$ in Riverside. When the two rates were added to provide a potential fertility rate it became clear that some districts with similar potential fertility rates had very different underlying component rates.

Such comparisons can be used for service monitoring, indicating the need for better abortion and family planning services in districts with high fertility rates and for better family planning services in those with high abortion rates.
\end{abstract}

\section{Introduction}

In 1971 there were 95000 legal abortions undertaken on women living in England and Wales and 783000 live births, a ratio of one abortion to just over eight live births. By 1986 there were 148000 legal abortions ${ }^{1}$ and 661000 live births, ${ }^{2}$ a ratio of one abortion to just over four live births. This paper describes the relation between fertility rates and legal abortion rates in
England and Wales and shows how these measures vary within a sample of health authorities.

The sample of health authorities was chosen by taking from each regional health authority in England and Wales the districts with the highest and the lowest fertility rates in 1986. Thus 30 district health authorities were sampled, which covered the total range of fertility in England and Wales in 1986 but not necessarily the total range of abortion rates.

\section{Methods}

As abortions and live births tend to occur to women at different ages one of the ways to compare fertility and abortions is by using total period fertility rates and total period legal abortion rates. These measures estimate the average number of live births or legal abortions which would be experienced per woman if women experienced the age specific fertility or abortion rates of the calendar year in question throughout their childbearing life span. The rates were derived by summing the fertility or legal abortion rate for a given year by single years of age, or age bands, across the fertile age range. These cumulative lifetime rates represent a variety of direct age standardised incidence rates without the arbitrariness of choosing a standard population. ${ }^{3}$ Both the data sets use the usual place of residence, rather than place of delivery or place of operation, which is preferable to information on place of medical care.

\section{Results}

A hypothetical average woman in England and Wales experiencing the present fertility rates through 